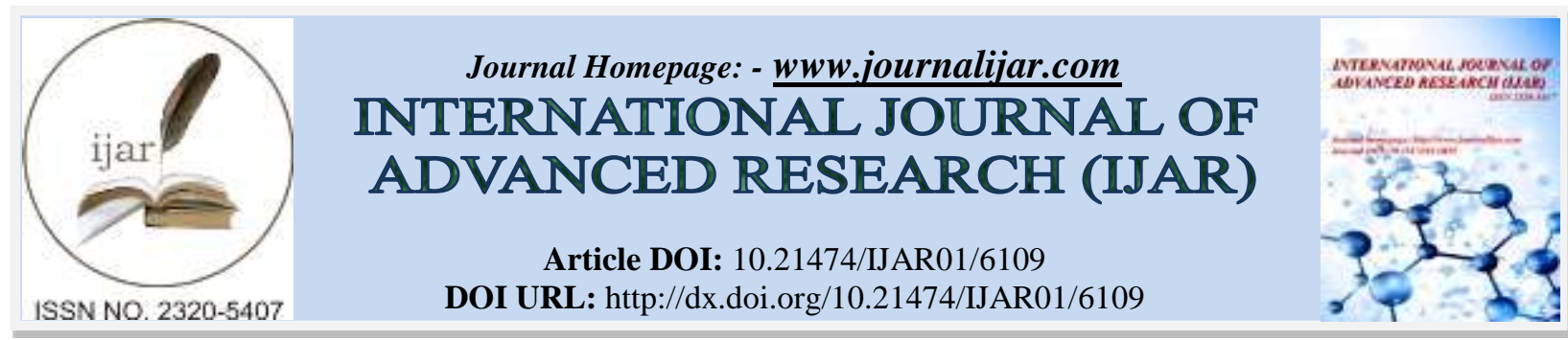

RESEARCH ARTICLE

\title{
THE EFFECT OF REGULAR EXERCISE AND SPORT MASSAGE ON MUSCULOSKELETAL PAIN IN RUNNER.
}

\author{
Novita Sari Harahap.
}

Faculty of Sport Science, Medan State University.

\section{Manuscript Info}

Manuscript History

Received: 19 October 2017

Final Accepted: 20 November 2017

Published: December 2017

Keywords:-

Muscle pain, regular exercise, sports massage.

\section{Abstract}

Musculoskeletal pain is the kind of pain or discomfort that occurs 1224 hours after physical activity. This is presumably caused by the accumulation of metabolic waste such as lactic acid in muscle and extracellular fluid causing irritation at the end of sensory fibers. The pain can be resulted by an inflammatory process or by exercise that involves many eccentric contractions. The objective of the study was to find out the effect of regular exercise combined with massage exercise on musculoskeletal pain.

The Subjects of this study were 40 young runners aged 18-19 years old. The subjects were randomly divided into 4 groups and each group consisted of 10 people such as, Regular Exercise combination group of sports massage (RE + SM), Regular Exercise group (RE), conventional combination group of sport massage $(\mathrm{CV}+\mathrm{SM})$ and Conventional group ( CV). Measurement of musculoskeletal pain used Visual Analogue Scale (VAS)

The results showed that a significant difference in average decrease in musculoskeletal pain on runners after exercise between RE + SM group and the RE group that was $(\mathrm{p}=0,000), \mathrm{CV}+\mathrm{SM}$ group was $(\mathrm{p}=$ $0,000)$ and $\mathrm{CV}$ group was $(\mathrm{p}=0.000)$.

The conclusion that Regular exercise combination of sport massage more lowered musculoskeletal pain than regular exercise without sport massage, Conventional Exercise and sport massage as well as Conventional Exercise.

Copy Right, IJAR, 2017,. All rights reserved.

\section{Introduction:-}

The optimization of athlete performance can be intensified, such as, preventing the onset of muscle pain due to exercise or called as musculoskeletal pain. Excessive exercise and eccentric contractions in muscle will cause musculoskeletal pain (Bakowski et al., 2008). Symptoms that often occur are muscle spasms, swelling, decreased muscle strength and local pain. This can appear in 24 hours after exercise and will disappear after 5-7 days (Chung et al., 2003). The musculoskeletal pain is a physiological effect on tissue that responds to activity received by the muscles. The musculoskeletal pain has impact on decrease of muscle strength that can affect to performance. The Musculoskeletal pain is kind of pain or discomfort that occurs within 12-24 hours after exercise and the recovery happens for 4-6 days. This is presumably caused by the accumulation of metabolic waste such as lactic acid in muscle and extracellular fluid causing irritation at the end of sensory fibers. This pain can also be caused by an inflammatory process or by exercise that involves a lot of eccentric muscle contractions (Bakowski et al., 2008). 
In addition, non-programmed exercises can lead to injury due to overtraining. This poorly controlled exercise can cause muscle damage, inflammation, and pain (Cheung et al., 2003).

The level of pain can be resulted by intensity of exercise given is not fair to individual ability either excessive muscle exercise or overtraining. This poorly controlled exercise can cause muscle damage, inflammation, and pain. If one is non-athlete, the damage resulted by muscle activity will outweigh ability to perform activities and there will also probably be wrong movement. The other factors are stiffness, contraction velocity, muscle fatigue, and position at the time of having a move (Cheung et al., 2003).

Tenderness can be localized to the muscle and may increase pain within 24-48 hours after exercise. This pain can describe how high receptor on the soft tissues and on the muscles. If it does not get proper care, it will result in sustained injury so as to affect to individual activity (Cheung et al., 2003).

The researchers found that exercise in twice a week significantly reduces joint pain (Stevenson et al., 2012). Physical exercises given affect to decreased joint pain and give positive effect on increased joint strength (Nauberger et al., 2007). The results are in line with a review of studies that say knee OA patients often taking aerobic exercise or muscle exercise at home can reduce pain and self-disability (Roddy et al., 2011). Physical exercises aim to preserve joint motion and have a major effect on decrease of pain intensity (Stevenson et al., 2012).

This study aims to find out the effect of regular exercise combined with sports massage on musculoskeletal pain.

\section{Method:-}

The subjects of this study were 40 runners aged 18-19 years old and had healthy body. Subjects were randomly divided into 4 groups and each group consisted of 10 people such as, Regular Exercise combination group of sport massage (RE + SM), Regular Exercise group (RE), Conventional Combination group of sport massage (KV + SM) and Conventional group ( KV). The study was conducted after obtaining approval from the Research Ethics Committee of University of North Sumatra, Medical Faculty with no.270 / KOMET / FKUSU / 2016. The exercise lasts for 8 weeks with frequency 3 times a week. Model of physical exercise in the group of RE + SM was weight training. At time of training was over, Sport massage was given on the lower leg by using effleurage technique for 12 minutes (6 minutes of right lower leg and 6 minutes of left leg). The way to practice effleurage was by rubbing the body using all the palms and fingers attached to the lower limbs, the motion began from the bottom to the top.

Pre test, the subjects of the study firstly warmed up for 15 minutes then the subjects run $200 \mathrm{~m}$. after finish, the measurement of musculoskeletal pain was immediately done by Visual Analogue Scale (VAS) presented in the form of horizontal line. The VAS method was given the numbers 0-10, each of them could show the intensity of pain felt by the patient (the left tip was marked "no pain" and the right one was marked "bad pain."(great pain). The subjects were given full freedom to identify the severity of the pain and marking it along the line as the level of pain intensity felt by the patient. After the exercise program was over, measurement of pain intensity was done as before the exercise program. The measurement data was tabulated and analyzed using ANAVA test.

\section{Result:-}

the analysis result of Anova test showed that there was a significant difference in the average decrease in musculoskeletal pain that was $(\mathrm{p}=0,000)$ after exercise in 4 groups such as Regular Exercise combination group of sport massage, Regular Exercise group, Conventional combination group of sport massage and Conventional group on runners, as shown in table 1.

Tabel 1:- Average Difference of musculoskeletal pain on runner in group $\mathrm{RE}+\mathrm{SM}$, group $\mathrm{RE}$, group $\mathrm{CV}+\mathrm{SM}$ and group CV

\begin{tabular}{|l|c|c|c|c|c|}
\hline \multicolumn{1}{|c|}{$\begin{array}{c}\text { Pain } \\
\text { intensity }\end{array}$} & RE + SM & RE & CV+SM & CV & Nilai p \\
\hline Pre-test & $3,6 \pm 0,52$ & $3,6 \pm 0,52$ & $3,6 \pm 0,52$ & $3,5 \pm 0,53$ & 0,964 \\
Post-test & $0,4 \pm 0,52$ & $2,5 \pm 0,53$ & $1,9 \pm 0,32$ & $2,9 \pm 0,32$ & $0,000^{*}$ \\
\hline
\end{tabular}

Information: * $=$ very significant $(\mathrm{p}<0,05)$, sd : standard deviation.

Figure 1 shows that considering continued analysis of the Bonferroni test, there was a significant difference in the average decrease in musculoskeletal pain on runners after exercise between RE + SM group and RE group that was 
$(\mathrm{p}=0,000), \mathrm{CV}+\mathrm{SM}$ group was $(\mathrm{p}=0,000)$ and $\mathrm{CV}$ group was $(\mathrm{p}=0,000)$. There was also a significant difference in average decrease in musculoskeletal pain between RE + SM group and RE group that was $(p=0.022)$ and $C V$ group was $(\mathrm{p}=0.000)$. This means that $\mathrm{RE}+\mathrm{SM}$ group lowers more musculoskeletal pain than $\mathrm{RE}$ group, $\mathrm{CV}+$ $\mathrm{SM}$ training group and $\mathrm{CV}$ training group, in addition the $\mathrm{CV}+\mathrm{SM}$ training group was better in reducing musculoskeletal pain in runners than RE group and $\mathrm{CV}$ training group.

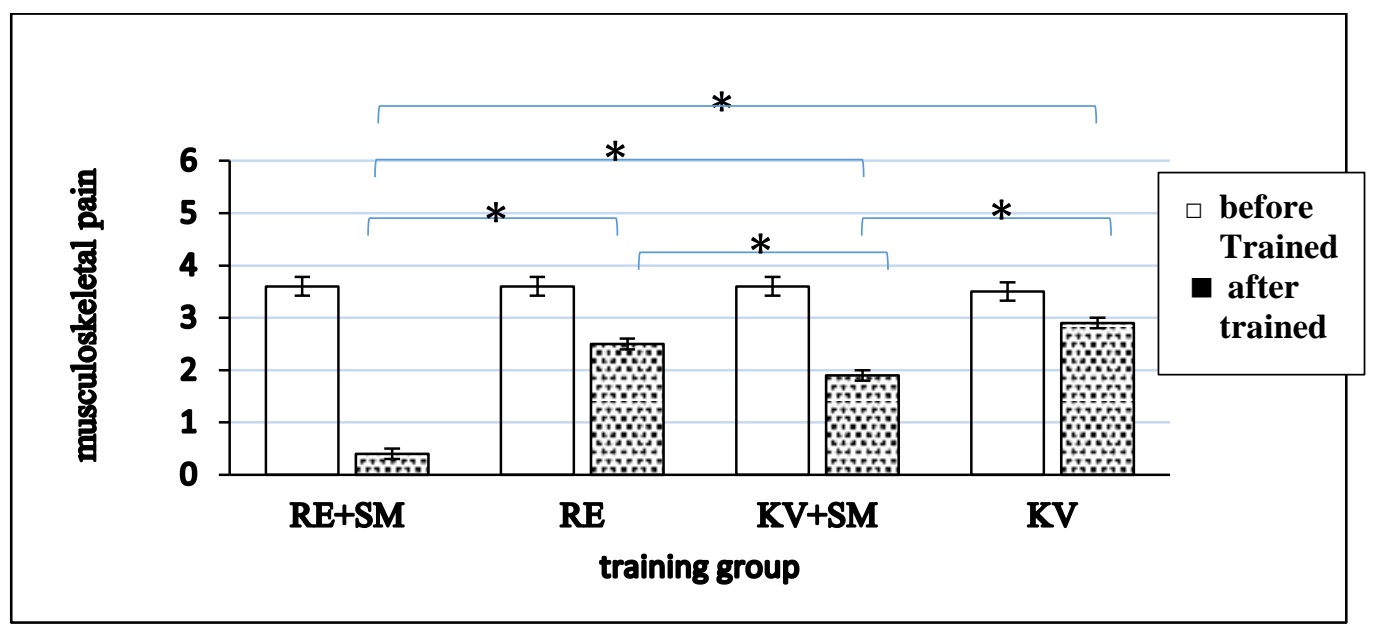

Figure 1:- Average musculoskeletal pain before and after training in group RE+SM, group RE, group CV+SM and group KV on $200 \mathrm{~m}$ runner, $*$ = significance $(\mathrm{p}<0,05)$.

\section{Discussion:-}

The Inflammatory response to muscles because strenuous exercise causes intracellular content and immuno response effect accumulated outside cells stimulates the nerve end of the muscle so as to damage muscle tissue and make musculoskeletal pain (Marquez et al., 2001).

The results of this study indicate that Regular Exercise combination of sports massage is better in reducing musculoskeletal pain because of the exercise not involving a lot of eccentric contractions in muscle, regular exercise and fair weight training to the individual ability. The musculoskeletal pain results from irritation of the ends of sensory fibers and inflammatory process caused by exercises involving multiple eccentric contractions of muscles. Regular exercise combined with sports massage helps to lower musculoskeletal pain because more optimal blood and oxygenation flow to muscle (Bakowski et al., 2008).

The results of this study are in line with previous research by Zainuddin et al. (2005) who states that sports massage after exercise will be more effective in reducing arm muscle pain without affecting to the muscle function significantly about $30 \%$ than the part of the arm that does not get massage. A study by Bakowski et al. (2008) on the subjects of 14 healthy men with no background of upper arm injuries and no experience in training showed that the arm getting massage has reduction of pain about to $10 \%-20 \%$.

Another result is a study by Jay et al. (2014) about the 22 untrained healthy men divided by 2 groups use the Visual Analogue Scala (1-10 scale). Day 1, all subjects were given a strong stimulus like exercise on hamstring muscle $10 \mathrm{x}$ 10 reps. Day 2, subjects in group 1 were given massage for 10 minutes on one leg meanwhile the other one is only as a control. The Subjects in group 2 rested for 10 minutes without massage. The result showed that group 1 that got massage had decreased pain $(\mathrm{p}=0.0001)$.

A study suggests that sport massage after exercise can reduce recovery time and prevent the onset of muscle pain after exercise (Hilbert et al., 2003). Sport massage can prevent muscle tension and increase the elimination of residual metabolism that is produced after strenuous exercise (Hemmings et al. 2000).

Body has a neuromodulator that can inhibit the transmission of pain impulses, one of which is beta-endorphins (Tamsuri, 2007). Endorphin works by blocking substance release process of $\mathbf{p}$ from sensory neurons so that the transmission of impulse pain in the spinal cord becomes obstructed, so it reduces the intensity of pain (Price \& 
Wilson, 2005). According to Arthritis Care and Research, regular exercise can stimulate the increased release of endorphins.

\section{Conclusion:-}

Regular exercise combination group of sports massage more lowers musculoskeletal pain than regular exercise without sport massage, Conventional Exercise and sports massage as well as Conventional Exercise.

\section{Acknowledgments:-}

This study is Doctoral Dissertation Grant financed by Directorate General of Research, Technology, and Higher Education in accordance with Research Contract Number: 045A / UN33.8 / LL / 2017.

\section{References:-}

1. Bakowski, P, Musielak, B, Sip, P, Bieganski, G 2008, 'Effects of massage on delayed-onset muscle soreness'. Chir Narzadow Ruchu Ortop Pol, vol. 73, no. 4, pp. 261-265.

2. Cheung, K, Hume P, Maxwell. 2003. Delayed Onset Muscle Soreness:Treatment Strategies

3. And Performance Factors. School of community health and sports studies, auckland

4. university of technology, auckland, new zealand. Sports med.,145-64

5. Cheung, K, Hume PA, Maxwell L. 2003. Delayed Onset Muscle Soreness Treatment Strategies And Performance Factors. Sports med ;33(2)145-164

6. Connolly, D, Sayers P, Mc Hugh P. 2003. Treatment And Prevention Of Delayed Onset Muscle Soreness. Journal Of Strength And Conditioning Research,17(1),197-208

7. Copland, S, Tipton John S, Karl B Fields. 2009. Evidence Based Treatment Of Hamstring Tears. Competitive sports and pain management. American College Of Sports Medicine.www.acsmr.org

8. Hemmings, BM, Smith, J, Graydon, Dyson, R 2000, 'Effects of massage on physiological restoration, perceived recovery, and repeated sports performance', British Journal of Sports Medicine, vol.34, no. 2, pp. 109.

9. Hilbert, JE, Sforzo, GA, Swensen, T 2003, 'The effects of massage on delayed onset muscle soreness', British Journal of Sports Medicine, vol. 37, no.1, pp. 72.

10. Jay, K, Sundstrup, E, Sondergaard, S, Behn, D, Brandt, M, Saervoll, C et al., 2014, 'Specificand cross over effects of massage for muscle soreness: Randomized controlled', The International Journal of Sports Physical Therapy, vol.9, no. 1, pp 82.

11. Marquez, RM, Singer, MA, Takaesu, NT, Waldrip, WR, Kraytsberg, Y, Newfeld, SJ. 2001. Transgenic analysis of the Smad family of TGF-beta signal transducers in Drosophila melanogaster suggests new roles and new interactions between family members. Genetics 157(4): 1639--1648.

12. Neuberger GB ${ }^{1}$, Aaronson LS, Gajewski B, Embretson SE, Cagle PE, Loudon JK, Miller PA 2007, 'Predictors of exercise and effects of exercise on symptoms, function, aerobic fitness, and disease outcomes of rhe umatoid arthritis'. Arthritis Rheum, vol. 57(6):943-52.

13. Price SA,Wilson LM. 2006. Patofisiologi konsep klinis proses-proses penyakit, edisi ke-6. Jakarta: EGC.

14. Rachmawati MR, Samara D, Tjhin P, Wartono M 2006, 'Musculoskelatal pain and its relationship with functional physical ability in the elderly'. Universa Medicina, vol.25 no.4.

15. Roddy E, Muller S, Thomas E 2011, 'Onset and persistence of disabling foot pain in community-dwelling older adults over a 3-year period: a prospective cohort study', J Gerontol A Biol Sci Med Sci, vol.66 (4):474-80.

16. Stevenson, TJ, Trinh, T, Kogelschatz, C, Fujimoto, E, Lush, ME, Piotrowski, T, Brimley, CJ, and Bonkowsky, JL 2012,' Hypoxia Disruption of Vertebrate CNS Pathfinding through EphrinB2 Is Rescued by Magnesium', PLoS Genetics, vol. 8 (4).

17. Tamsuri, 2007, Konsep Dan Penatalaksanaan Nyeri EGC, Jakarta.

18. Zainuddin, Z, Newton, M, Sacco, P, Nosaka, K 2005, 'Effects of massage on delayed-onset muscle soreness, swelling, and recovery of muscle function', Journal of Athletic Training, vol. 40, no. 3, pp. 174-180. 